\title{
West Nile Virus Antibody Measurement
}

National Cancer Institute

\section{Source}

National Cancer Institute. West Nile Virus Antibody Measurement. NCI Thesaurus. Code C147448.

The determination of the amount of West Nile virus antibody present in a sample. 